\title{
From active research to science publishing
}

\author{
For a flavour of life in scientific publishing, it seemed appropriate to take a \\ stroll around the Nature offices. Every journal, of course, is different, but \\ Nature's staff here give an idea of the range of editorial-related jobs available \\ on journals and what they, as recruiters, look for.
}

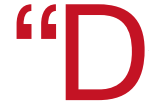
o you miss active research?" That was the question I dropped into the email boxes of Nature's staff, curious to know how they felt about a career away from the laboratory. The answers ranged from a resounding "no" to the more qualified "not seriously" given by Philip Campbell, Nature's editor. "Occasionally, I've been enthused by a particular scientist's description of a problem, and envied his or her being wrapped up in it, but then I move on," he says.

"Ilove the breadth of the science [we publish]," says Rory Howlett, Nature's deputy biology editor. "When you are doing active research you can become too narrow and lose touch with what you loved about science in the first place." From the physics editors the answer was similar. "I feel more immersed in science than ever," says Karen Southwell. There are times, though, when she misses research "a little". How much that has to do with being an astronomer who previously visited telescopes in exotic locations is, she admits, not clear.

At a more serious level, Southwell is glad that she moved to Nature, because "there is

\section{love the breadth of} science [we publish]... ...When you are doing active research you can become too narrow and lose touch with what

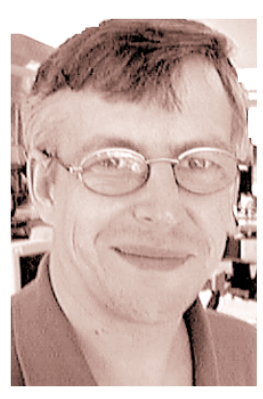
youloved about science in the first place Rory Howlett no security in academia and I never fancied being a lecturer". As exciting and satisfying as research can be, lack of security is undoubtedly one of the downsides highlighted by Nature's staff as a reason for leaving academic research. Poor pay and lack of career structure were others. Henry Gee, Nature's senior science writer and the editor responsible for palaeontology, says that his superiors "were forever on the insecure, nomadic postdoc trail". Now, says Gee, "I get all the intellectual thrill of being a scientist without any of the misery." He is also paid a salary roughly equivalent to that of a senior lecturer.

\section{Varied roles}

The thrill comes from exposure to the cutting edge of science reported in the manuscripts submitted to Nature. Because papers are the heart of any scientific journal, it is jobs like Gee's, Howlett's and Southwell's as editors that spring most readily to mind when thinking of a career in scientific publishing. But graduates contemplating such a career should be aware that the responsibility and content of an editor's job varies considerably from journal to journal, and it is worth doing research on any publication you might consider working for. The job can, for example, be primarily administrative, liaising with the editorial board and peer reviewers, or it can involve basic copy-editing, proof reading and working with production.

In large part, the editor's degree of responsibility depends on whether the journal has an editorial board and how extensive and influential the board is in determining the journal's editorial content. Nature and her sister publications do not have editorial boards. Although peer review naturally remains the means of assessing technical quality, it is the editors, not a board, who select the reviewers and who decide on editorial grounds which paper - assuming it passes peer review - is published. This makes the role of an editor on journals in the Nature family somewhat different from that on many specialist journals.

Nature's editors send roughly 20 to 30 per cent of the papers received for peer review. If get all the intellectual thrill of being a

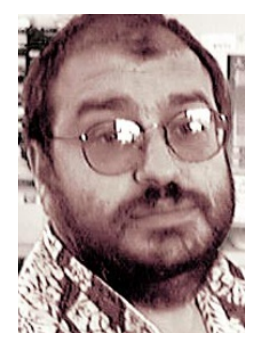

scientist without any of the misery

Henry Gee

the work is reviewed favourably, the editors might still decide on editorial grounds that it is not of sufficient interest. Then again, perhaps two reviewers say the work is good but one says it isn't. The work is not necessarily published. "It's not a democracy," says Howlett, arguing that the two may not make as good a case for their view as the one. "We are looking for independence of mind in our editors," says Campbell.

During 1999, Nature expanded the number of biology editors and looked for people with postdoc experience from good labs. "We want people who, if they were to stay in science, would have a bright future," says Howlett. "We are not looking for refugees." Anyone applying to be an editor on Nature titles (and, although they operate somewhat differently, to other top journals like Science or $(\mathrm{lll})$ will need to demonstrate excellent academic qualifications, specific knowledge of their discipline and an awareness of the big themes in science. They can expect stiff competition for the job.

\section{Day-to-day tasks}

The key tasks of being, say, a biology editor at Nature involve taking your share of the 100 to 120 biology manuscripts that arrive in the office each week. Each editor has an area of core expertise, such as neuroscience or ecology, and two or three satellite areas. Maxine Clarke, the journal's executive editor who has responsibility for the cell biology and biophysics of 'motor' proteins, says, "I get a kick out of trying to attract the 
best research in my field and in publishing the top articles."

On average, only 10 per cent of the total papers received by Nature appear in print. Once accepted they go to a subeditor, whose job it is to work on the text so that the ideas are accessible, the style consistent and the figures and tables presented clearly. Unlike more specialist publications, Nature aims to make its scientific papers as understandable as is practicable to a general scientific audience, meaning that subeditors may have to rewrite parts of the papers into more accessible English. On another journal the subeditor's job may be done by a manuscript or desk editor.

A subeditor on Nature will probably, like Rachel Smyly, have a PhD or some research experience. Smyly studied natural sciences at the University of Cambridge and did a couple of years of research. "It's good to be exposed to so much exciting science," says Smyly. "As a subeditor, my responsibility is to ensure that papers are understandable and interesting to scientists from other areas of research.”

Although not as narrowly focused as an active researcher, Nature's editors are quite specialized. The News and Views section, therefore, bridges the gap between hard-core manuscript publishing and the kind of science features written for a lay audience that are found in magazines like Scientific American or New Scientist. News and Views articles, written by scientists, put current research in context for readers in other fields.

Tim Lincoln, who has degrees in biology and oceanography, heads the team comprising himself, a biologist and a physicist responsible for commissioning and editing the section. When he is recruiting, Lincoln looks, obviously, for good academic qualifications. Everyone on his last short list had a first-class degree, although a good candidate with a 2(i) would not have been excluded. Given that an important part of the job is use of language, candidates are expected to be native English speakers. Strong candidates from outside the UK would be flown to

\section{n publishing you often start with} unglamorous jobs, and

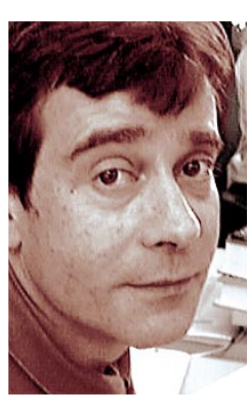
what happens next is what you make of it

Tim Lincoln

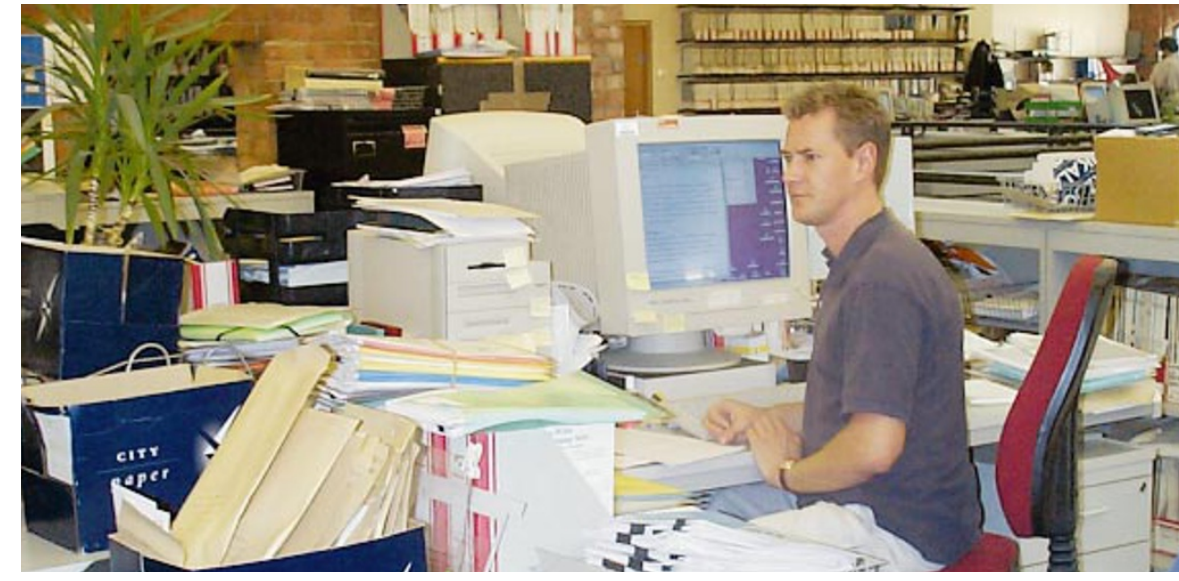

In choosing a career in scientific publishing, Nature's editors are exposed to the cutting edge of science.

London for interview. At interview the candidates need to show confidence, and demonstrate enthusiasm and an ability to communicate well with others, as well as a reader's knowledge of Nature. Without these attributes, brilliant academic qualifications are not enough. "I'm an enthusiast and I like to work with enthusiasts," says Lincoln.

\section{Avoiding pitfalls}

What excludes a candidate? Typographical errors or poor spelling in the application letter are an automatic barrier. "The production team doesn't stand by with outstretched arms to catch us," says Lincoln. One of the fastest ways to hit the bin is to send an application letter that sounds like a round robin or fails to demonstrate a knowledge of Nature (for Nature, substitute the title of whatever journal or employer you are seeking work with).

Sarah Tomlin, who commissions physics News and Views articles, did not make those mistakes. She has a PhD in biophysics and was one of 60 applicants. There were 260 candidates for the biology News \& Views post, doubtless reflecting the subject's popularity on the eve of the so-called century of biology. Given that all of the applicants on Lincoln's short lists have good academic qualifications, the question arises as to what gives a candidate an edge. A huge plus with Tomlin's application was that she had written a science column for her student newspaper, and so demonstrated an enthusiasm for science communication. "It was hard work finding a job in the field I wanted," says Tomlin. "These sciencerelated communication jobs come up very rarely."

The comment is fair warning. So here are a few tips. "Out of every 100 people who consider a career in publishing or journalism, 95 want to write. It's a rarity to come across people who want to edit," says Lincoln. His advice, therefore, is to look for jobs in production or as a subeditor. Lincoln's career started in book production at Academic
Press. "The pay was dismal," says Lincoln, "but in publishing you often start with unglamorous jobs, and what happens next is what you make of it."

Remember also that unsolicited letters to publishers do sometimes get read. Poorly written 'form' letters are discarded immediately, says Clarke, but "if someone takes the trouble to write a good letter, I like to respond". Both Lincoln and Stephanie Pain, now associate editor at New Scientist, sent letters to publishers when starting out, and several months later received letters asking them if they were still interested in a post.

In addition, consider postgraduate training in journalism, editing or production at an institution such as the London College of Printing (www.lcp.linst.ac.uk), Cardiff University (www.cf.ac.uk/uwcc/jomec/), London's City University (www.city.ac.uk/ journalism) or the University of Sheffield (www.shef.ac.uk/ j/). Monitor The Guardian (www.jobsunlimited.com) on Mondays for jobs and courses in the media, and study the classified sections of Nature (www.nature.com) and New Scientist (www.newscientistjobs.com) regularly.

Finally, look out for jobs on specialist publications. Dennis Pilling, who is responsible for acquisitions at the British Library, says that there were 8,618 science, technology and medical serial publications deposited at the library in 1998/99. Some of these will be specialist publications aimed at, say, the building trade, electronics or computing. These publications include news and features about issues affecting their readers and, if your aim is to be a journalist rather than work on manuscripts, these publications are a good place to learn and develop the skills needed. Besides offering a good career structure, the 'trade and techs' can be a route to the nationals, consumer magazines or the kind of science policy reporting published in journals like Science and Nature. 